Document downloaded from:

http://hdl.handle.net/10251/176063

This paper must be cited as:

Gil Benso, E.; Mas Tomas, MDLA.; Lerma Elvira, C.; Torner, ME.; Vercher Sanchis, J. (2021). Non-destructive Techniques Methodologies for the Detection of Ancient Structures under Heritage Buildings. International journal of architectural heritage (electronic). 15(10):1457-1473. https://doi.org/10.1080/15583058.2019.1700320

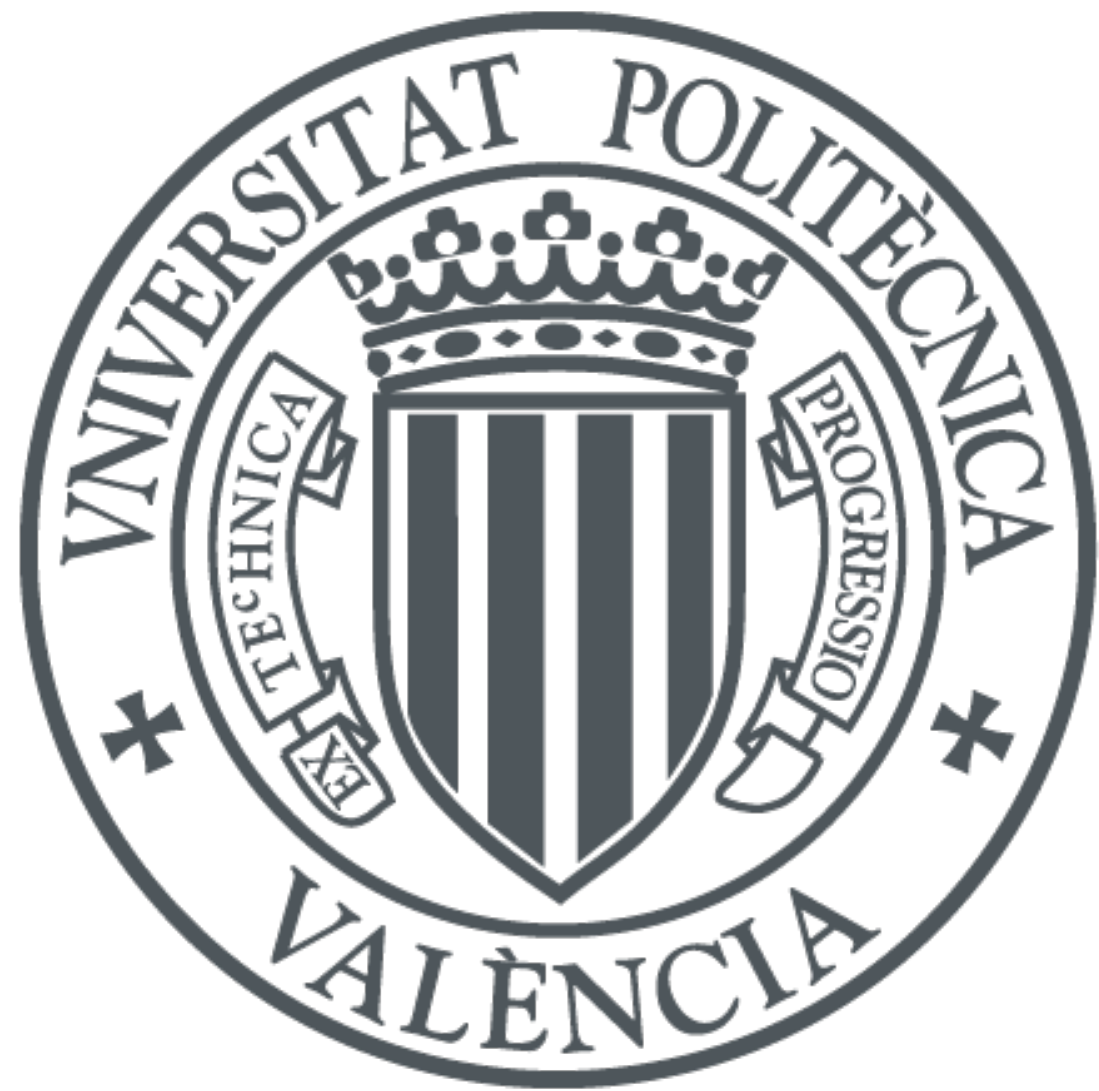

The final publication is available at

https://doi.org/10.1080/15583058.2019.1700320

Copyright Taylor \& Francis

Additional Information 
Non-destructive techniques methodologies for the detection of ancient structures under heritage buildings

Enrique Gil ${ }^{\mathrm{a}}$, Ángeles Mas ${ }^{\mathrm{b}}$, Carlos Lerma ${ }^{\mathrm{b} *}$, M. Eugenia Torner ${ }^{\mathrm{a}}$ and Jose Vercher $^{\mathrm{b}}$

${ }^{a}$ Dept. of Continuous Medium Mechanics and Theory of Structures, Universitat Politècnica de València. Camino de Vera s/n, 46022 Valencia, Spain.; ${ }^{b} D p t$. Architectural Constructions, Universitat Politècnica de València. Camino de Vera s/n, 46022 Valencia, Spain.

*Corresponding author: Carlos Lerma (clerma@csa.upv.es) 


\title{
Non-destructive techniques methodologies for the detection of ancient structures under heritage buildings
}

\author{
Structures and elements buried beneath heritage buildings are frequent but are \\ often unknown and inaccessible. Therefore, they are difficult to locate in general \\ if an archaeological excavation is not carried out, with the economic cost and \\ time involved. It is important to discover them in order to increase our knowledge \\ of cultural heritage, as well as to know, recover and improve the state of \\ conservation of the materials that make up these structures. This paper presents \\ methodologies for locating old structures using a low-cost NDT approach, with a \\ qualitative and quantitative analysis of GPR profiles in heritage buildings. Small \\ perforations are performed at critical points and introducing an endoscope for \\ verification. Various crypts have been located using the proposed methodologies \\ in a real study case: The Church of the Asución of Llíria in Spain.
}

Keywords: Ancient structures; heritage; crypt; brick; GPR; NDT.

\section{Introduction}

In many cases, investigations of the subsoil in heritage buildings seek a better knowledge of old structures and their location before proceeding to their restoration $[1,2]$. Preventive conservation methods are focused on determining and controlling the processes of cultural heritage deterioration [3] trying to optimize resources with lowcost methods [4]. This paper develops a methodology that analyses ancient structures under heritage buildings with a low economic cost. Non-destructive techniques (NDT) allow the collection of geometric, historical and structural information [5-9], as well as fractures, voids or cracks [10-12], with a combination of advanced and simplified analytical methods to perform predictive analysis of the structural behaviour [13-14], and the monitoring of building materials and the identification of their pathology [1517]. NDT has been used as a monitoring tool of the works progress and the assessment of materials and rehabilitation interventions [18]. Some experimental activities (e.g. drilling or core sampling) can be considered as minor intrusive/destructive for the 
global constructions, since they are very localized and easily repairable [19]. In this sense, the detection of ancient structures such as tombs, crypts, cavities and other archaeological structures has also been successfully carried out by NDT [20-24]. The Ground Penetrating Radar (GPR) technique is based on the displacement, through a surface, of an antenna transmitting electromagnetic waves that are captured by a receiving antenna. Depending on the inequalities between the emitted and received signal, various anomalies can be shown [25]. GPR has been used to discover previously unknown constructions [26-27] and provide useful information for the identification and characterization of archaeological remains buried at different depths [28].

The electromagnetic velocity field represents the most important information that can be extracted from field data, but the inherent limitations of the velocity estimation performed on common offset data for GPR surveys collected reduce the accuracy of any derived quantity, while multi-fold methods to GPR investigation can partially overcome such problem [29]. Continuous and real-time monitoring is important for GPR implementation [30] and automated methods produce a plan view map of amplitude of GPR signals [31]. GPR technology has been widely studied [3237] also the presence of anthropogenic buried cavities partially filled with rubble material has been studied with GPR [38]. GPR can allow to identify the areas with alleged interesting buried remains, which in turn allow to avoid an exhaustive and expensive excavation [39]. Buried structures, air chambers or groundwater can be located, although the search for cracks or moisture differences has proved unsuccessful [40]. The ability of GPR to visualize buried units can help to understand burial and preservation phenomena [41]. GPR profiles are based on the propagation characteristics of the electromagnetic signal of the antenna. When the terrain is very homogeneous and there are no significant variations, the amplitude of the wave is reduced for all points, 
but if there are important changes in the properties of the terrain, there is water or cavities, then the amplitude of the wave increases significantly. Buried structures can also modify the amplitude of the waves.

From a historical point of view, in the sixteenth century the floor of churches was marked to allow the greatest number of graves with a price that varied from more to less as they moved away from the altar. The Braga Council (561) prohibited burial inside temples in the High Middle Ages, although from the 13th century onwards burials inside churches became widespread [42]. In Spain, it was not until 1786 that King Carlos III ordered the creation of cemeteries outside the population centres for reasons of hygiene and public health. Although dimensions may vary, each grave was a narrow rectangle 7 feet long and 3.5 feet wide (approximately $2 \times 1 \mathrm{~m}^{2}$ ) [43].

The nobility found it interesting to invest part of their capital in sumptuous burials that would perpetuate their memory for eternity. It was both a way to show their power and to have a sepulchre adequate to the dignity they had in life. This way of proceeding was a common practice in the construction of large religious buildings, as a means of financing to cover the enormous costs involved in the works [44]. However, the most senior deceased (bishops, priests, mayors, sponsors of foundations, etc.) were those who were buried in the crypts of the temples [43]. A contract was usually made specifying the dimensions of the underground chapel, the materials to be used, the architectural elements chosen, the shape of the cover, etc. so that the master of the work would have a clear guide when working and from which, of course, he could not deviate [44]. The crypts provided an opportunity to substantially increase the number of chapels and altars, thus enriching the liturgical life of the new sanctuary built [45].

This manuscript presents a methodology that combines several analysis techniques of GPR profile for the detection of buried structures of archaeological 
interest under heritage buildings. A qualitative and quantitative approximation of the GPR profiles has been applied in a real study case: The Church of the Asunción of Llíria (Valencia, Spain). Finally, predictions based on GPR profiles are validated against the results of a low-cost endoscope survey.

\section{The Church of the Asunción of Llíria}

The Church of the Asunción of Llíria (Valencia, Spain), which is one of the most important Baroque temples among the architectural examples of this period in Spain [46-49], has been used for the development of the methodologies presented in this paper (Figure 1). The church reflects clearly the Counter-Reformation laws as its construction began in 1626 and lasted until 1783 [50]. The location of the building is important (Figure 1a), as well as being an outstanding architectural work [51,52]. At the same time, the main square was enlarged to integrate the church and house more representative buildings with the intention of creating the main nucleus on a flat area, considering the increase in population and the growth of the city [53], and hence conform to Aliaga's recommendations [54].

The church of the Asunción of Llíria unfortunately lacks reliable data on burials due to the absence of a good number of books from its parish archive. It is known that in July 1642 a decree was issued allowing the transfer of the graves of 85 families from the old church to the new one, as the works of the first body of the church were being completed [54].

In addition, in August of 1772 the materials and the execution of the niches belonging to the main crypt were described [54]. This coincides with the construction that is known. However, in the design and construction of a crypt, it should be taken into account that when excavating the ground, foundations of old constructions or water problems could arise, so that it could undergo modifications [44]. 

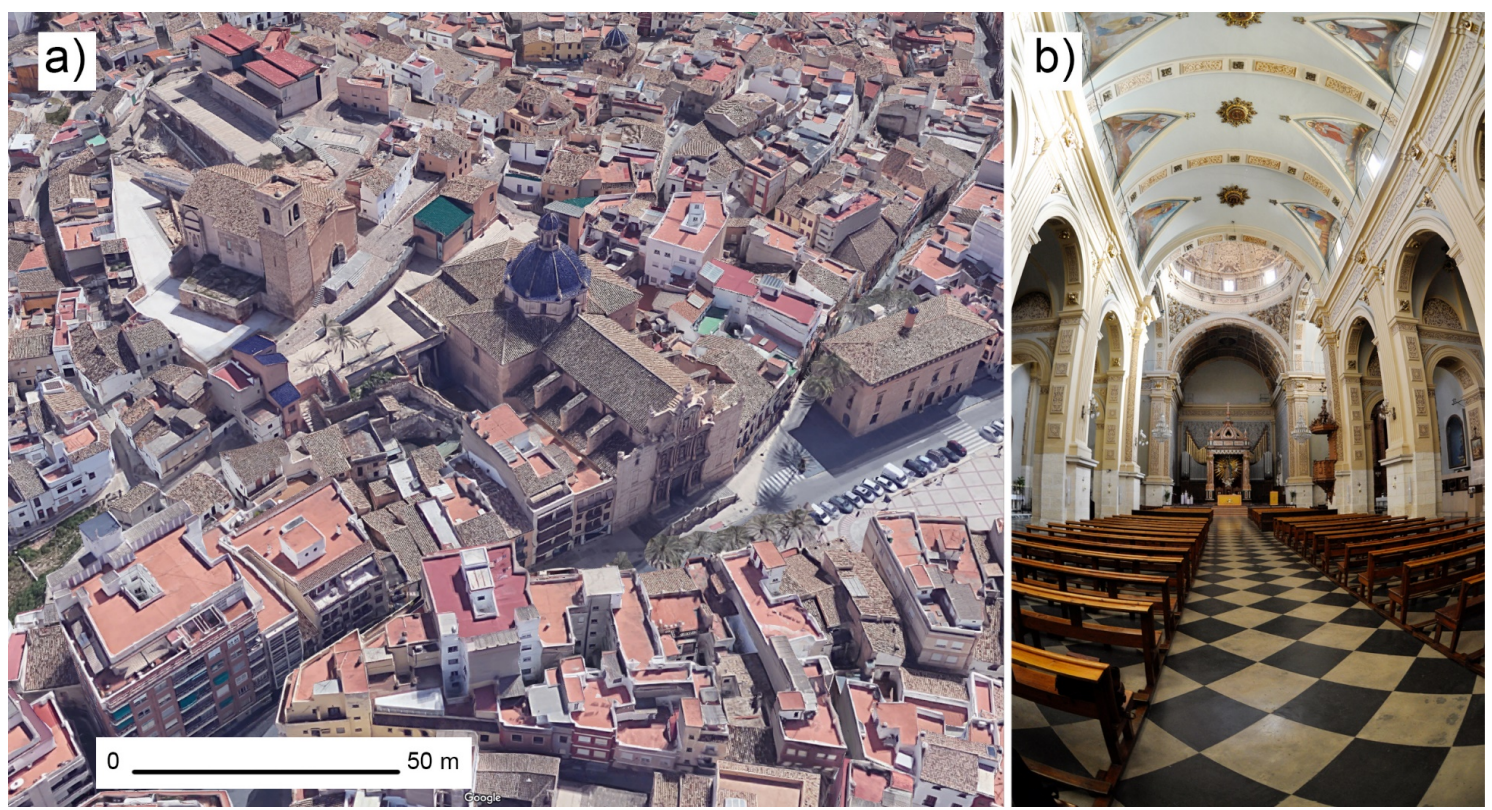

Figure 1. (a) Aerial view of the Church of the Asunción of Llíria (Source:

Google \& National Geographic Institute of Spain). (b) Interior view of the central nave of the church.

The use of the mensiochronological analysis criterion of the brickwork is very relevant for the dating of the structures buried in the church of Llíria, especially the main crypt. Dimensions of bricks and thickness of mortar joints can contribute a clear orientation of the century in which they were built [56-65].

Essentially, the materials used in the construction of the church of Llíria were stone and brick. For the construction of the church it was necessary to obtain a flat and horizontal surface, so it was necessary to demolish part of the mountain next to the church. This mountain served as a quarry providing abundant stone for the construction of the church. The church is founded partially on the rock constituting the close mountain and partially on a $15 \mathrm{~m}$ thick silt-clayey sand. The foundation of the building is assumed to be of stone material. The water table, obtained by tastings is very superficial, between -1.80 and $-3.00 \mathrm{~m}$ depending on the season. The water level was $-3.00 \mathrm{~m}$ from the ground level of the church floor when the GPR tests were executed. 
The dimensions of the materials can indicate the time they were placed. In this sense, studies carried out in Valencian buildings of the seventeenth and eighteenth centuries indicate that brick thickness has varied between 35 and $45 \mathrm{~mm}$. The thickness was the first to increase in size, then it stabilized, and at the end of the 18th century it descended slightly. In Valencia, in the seventeenth century, the bricks are thin (32-35 $\mathrm{mm})$ and the tendels are thick $(40-45 \mathrm{~mm})$. In the 18th century, with a more controlled production, the bricks have a thickness of $40 \mathrm{~mm}$ and tendels of 22-34 $\mathrm{mm}$ [64], as expected in masonry of the structures buried in the church of Llíria.

This type of burial continued until January 1818 when the blessing of the new Cemetery was celebrated. Its location was outside the walls, far from the population as demanded by the Royal Decree of 1787 [55].

\section{Methodology}

In the first place, the stratigraphy was studied with the objective of determining the type of buried structures located in the church. This survey was conducted in order to collect data that would allow defining the architectural elements of the subsoil (foundation elements, foundation beams, crypts, etc.) and the location of possible accesses for an archaeological intervention. This was decided to use the endoscopic technique, which is minimal intrusive, due to its null impact in the intervention and its minimal economic cost.

The novel methodology proposed in this research consists of four different ways of analysing GPR profiles quantitatively. A qualitative study of the observation of these profiles has also been carried out. The qualitative technique tries to find the most significant points to excavate by observing the GPR profiles. Thus, intuitively, areas with higher densities are searched, which are not homogeneous, with a study of the 
parabolas generated by the georadar signal. In addition, NDT approach were employed to confirm location and dimensions of ancient structures under heritage buildings.

A quantitative analysis of GPR profiles complements the qualitative evaluation. The first analytical technique groups in intervals the amplitude of the signal for each profile and allowing a comparison among them. The second technique searches for depth where there is a first important change in the amplitude of the signal. The variation of the adjustment models in the attenuation of the GPR signal is evaluated in the third technique. Finally, the fourth analysis technique uses software filters to measure the changes in signal propagation conditions.

The steps developed in this section are: Previous documentation; Georadar survey; Analysis of georadar profiles; Drilling campaign; Visualization and measurement by low-cost endoscope.

\subsection{Performed experimental tests}

Important architectural documentation of the Municipal Archive of City Council and the archives of the church were destroyed during the Spanish Civil War (1936-1939). The war destroyed drawings and other elements of the church, including the main part of the building documentation [54]. The necessary graphic documentation to elaborate plants and sections of the church was made by means of a 3D scanner.

There is a crypt, which is known and accessible, allowing to obtain very valuable information about the construction of this funerary structure. It is a space next to the entrance door. This crypt consists of six niches on each side and a lower space, where formerly a wooden floor was placed, to save the water coming from the subsoil. A brick vault with the horizontal rope and the vertical (rowlock position) that has a continuous coating of lime mortar is observed in the upper part. It is an accessible crypt 
designed with six arches on each side, which constitute the niches for burials, which is built with the prescriptions found. This buried structure below the water table usually contains groundwater that circulates through the land. Long standing water leaves horizontal marks on the side walls of the crypt, which can clearly be seen in Figure 2-a. The niches are built with brickwork covered with lime mortar and the crypt is built under a brick vault. The main niches rest on larger arches, possibly designed as ossuaries, but flooded continuously (Figure 2-b).
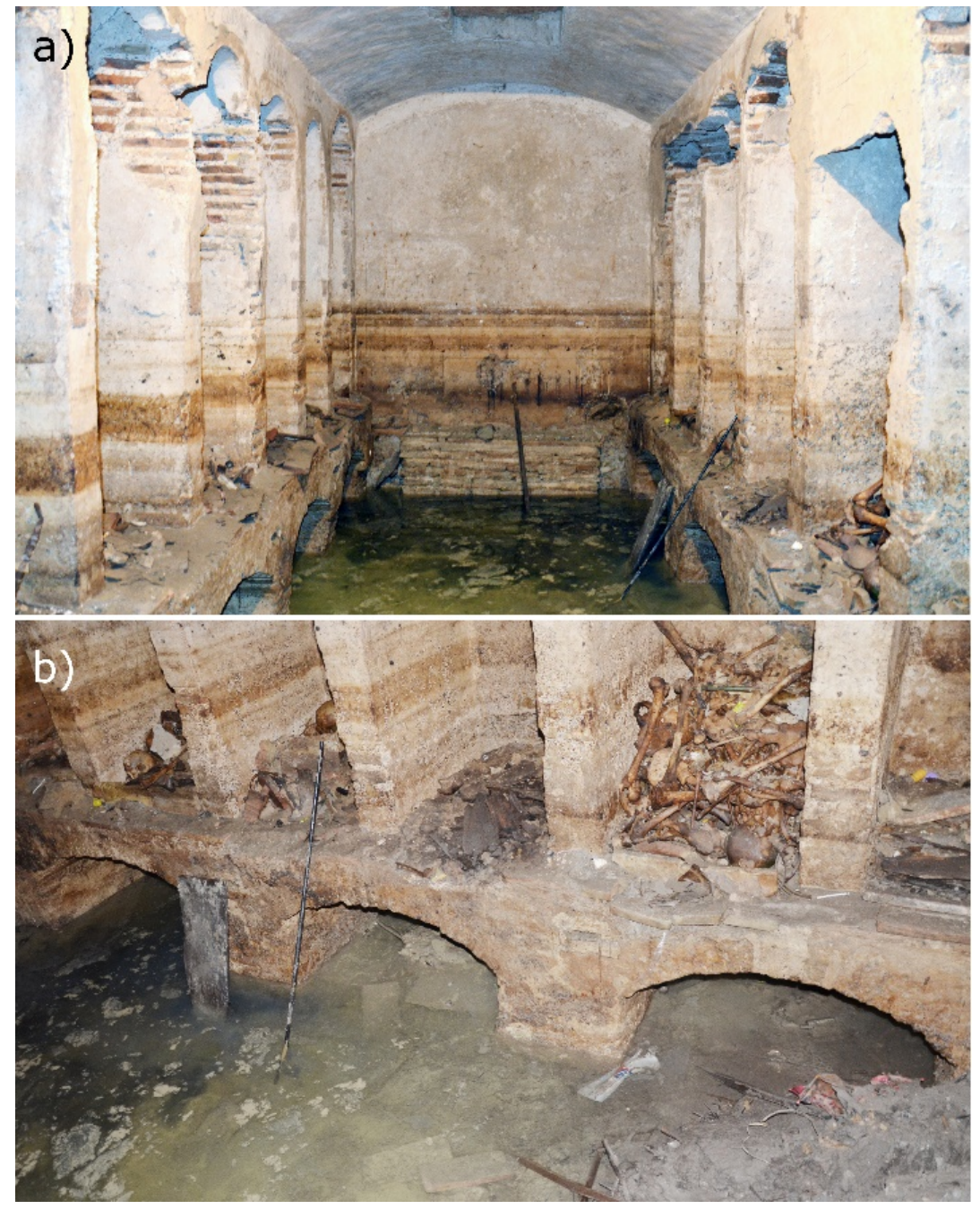

Figure 2. Interior of the known crypt: (a) General view; (b) Detail of the vault.

The campaign of data acquisition through GPR Sir model 3000 with $200 \mathrm{MHz}$ antenna (Table 1) allows its application for approximately $2 \mathrm{~m}$ deep (Figure 3 ). Higher 
frequency antennas (500-800 MHz or more) must be used for higher resolution, but they reduce the depth that can be observed. The characteristics of the antenna $(200 \mathrm{MHz})$ is the most appropriate option for the intervention that has been carried out, since it allows to obtain subsoil information between 0 and 2-3 m depth.

Table 1 GPR Sir model 3000 specifications.

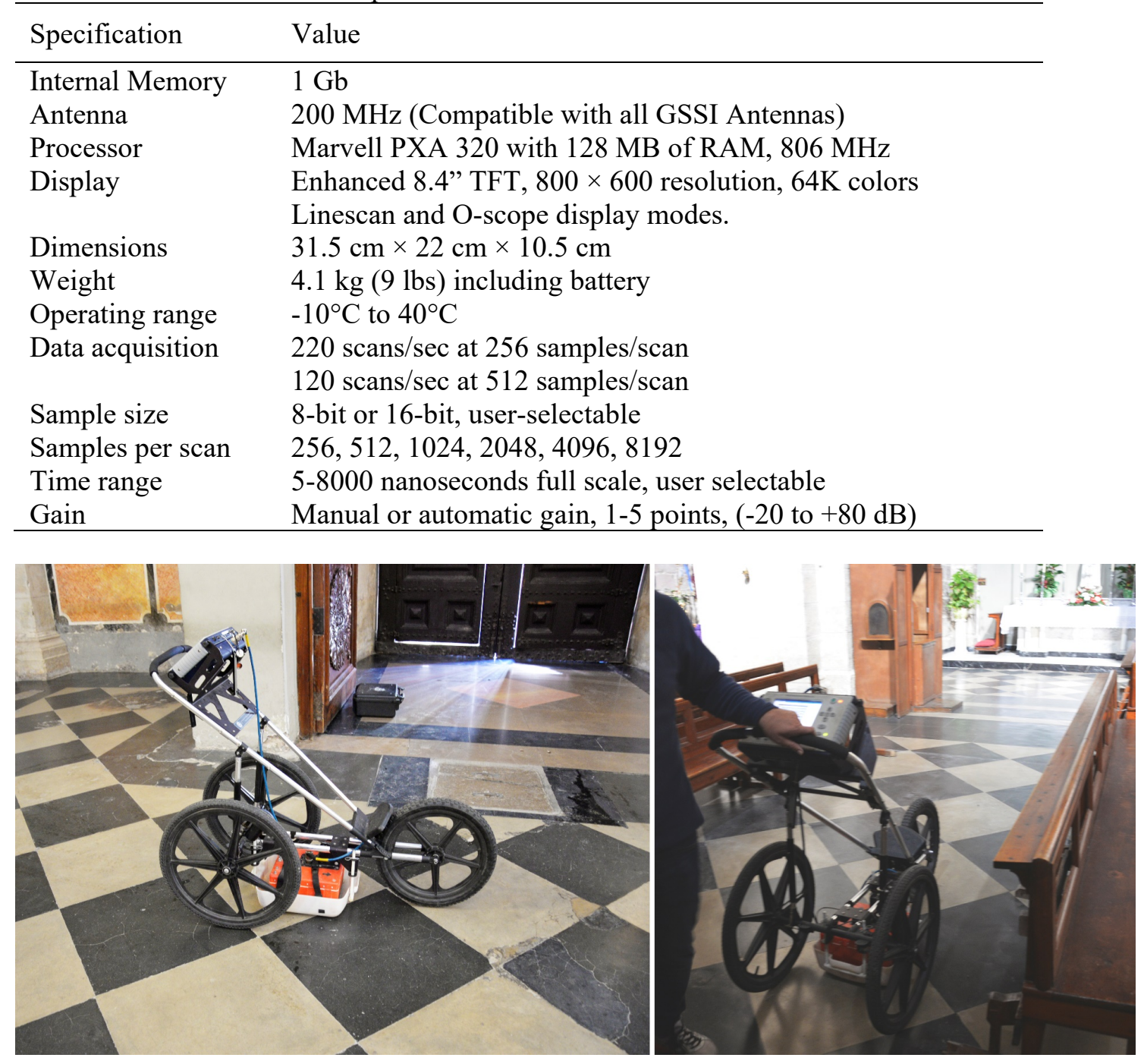

Figure 3. GPR Sir model 3000 with $200 \mathrm{MHz}$ antenna used in the church of the Asunción of Llíria.

It is necessary to establish a previous pattern of the different profiles that were wanted to obtain with the georadar (Figure 4). In a religious building, such as this church, the central nave and the lateral naves are very important, so longitudinal and 
transversal profiles were taken to these spaces, in anticipation of finding crypts or other funerary cavities. At least one longitudinal profile is made in each nave of the church and transversal profiles in each of the openings (chapels and transept). An important number of GPR profiles with small length are made when a possible structure is detected in situ in order to provide more data. Figure 4 shows the 30 profiles of the georadar campaign, with the position, dimension and direction of each of the profiles on the building floor. The length of the profiles was obtained by a laser meter. The location of the known crypt is indicated in plan and section, since it has influenced when deciding the number and position of profiles to be made. The starting position, direction and length of each of the GPR profiles taken is recorded during the campaign (Table 2).

Table 2. Data of the GPR profiles in the church.

\begin{tabular}{ll|ll}
\hline Profile & Length $(\mathrm{m})$ & Profile & Length $(\mathrm{m})$ \\
\hline P1 & 43.16 & P16 & 6.94 \\
P2 & 40.43 & P17 & 6.94 \\
P3 & 39.88 & P18 & 4.56 \\
P4 & 22.10 & P19 & 4.56 \\
P5 & 21.43 & P20 & 4.56 \\
P6 & 20.48 & P21 & 4.58 \\
P7 & 20.48 & P22 & 4.58 \\
P8 & 20.50 & P23 & 4.58 \\
P9 & 19.47 & P24 & 4.58 \\
P10 & 19.47 & P25 & 4.58 \\
P11 & 25.47 & P26 & 4.58 \\
P12 & 26.16 & P27 & 2.30 \\
P13 & 25.47 & P28 & 5.02 \\
P14 & 6.94 & P29 & 4.74 \\
P15 & 6.94 & P30 & 4.54 \\
\hline
\end{tabular}

In particular, the direction (longitudinal or cross), the orientation (the direction of data acquisition: towards the N, S, E, W) and the exact length are indicated from the 30 GPR profiles considered. The most representative profiles have been selected for this work, those that contain more information discarding those that are symmetrical or similar. 


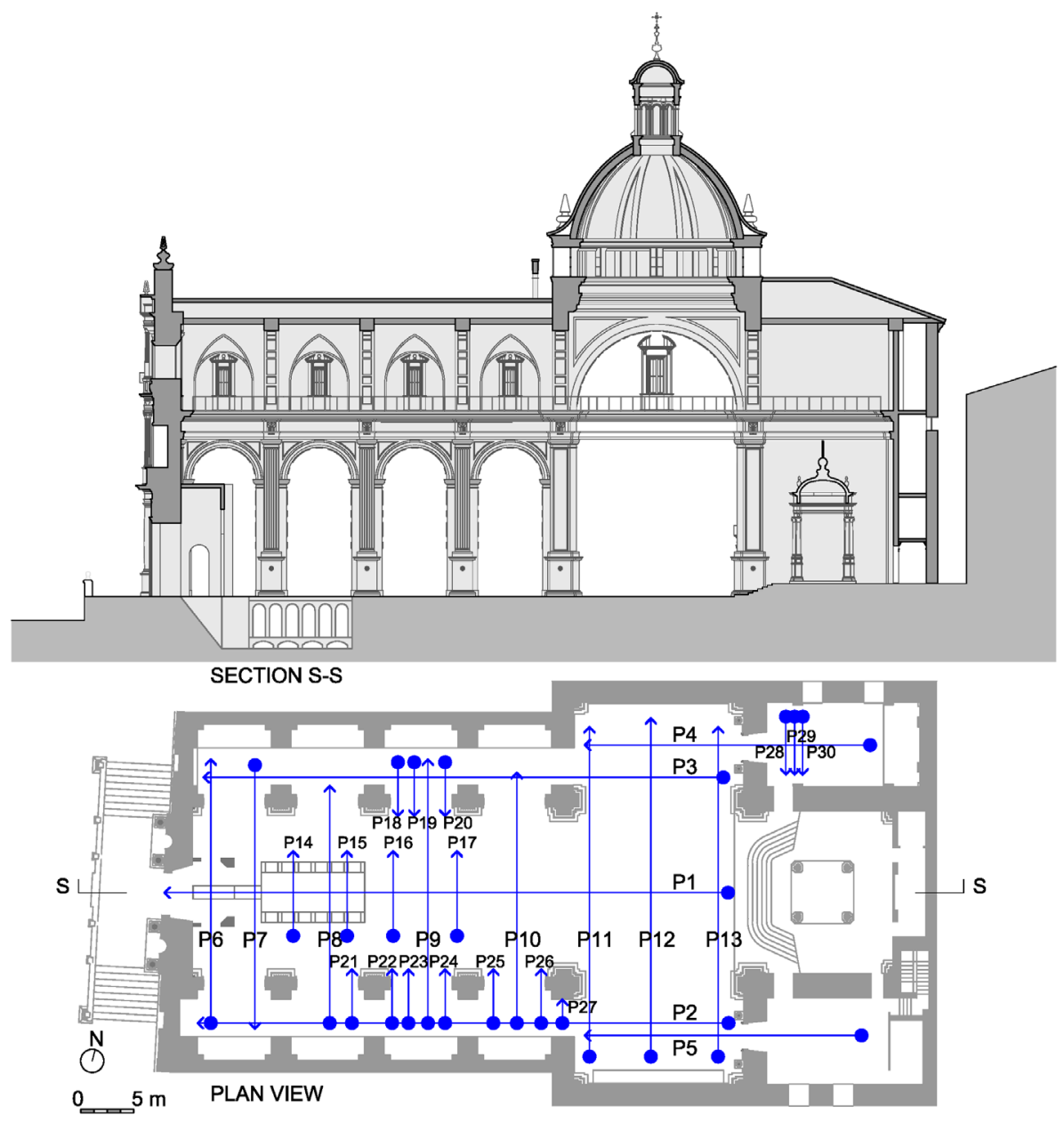

Figure 4. GPR profiles in the church. Plan view of the church with the location of the profiles and longitudinal section S-S.

The data which can be extracted from the GPR profiles are analysed once they have been obtained.

This work is focused in the analysis techniques and the use of the endoscope and GPR signal processing has sought only to compensate for the variation in signal amplitude. The exponential fit model allows losses to be corrected more effectively:

$$
t_{i}^{\prime}=t_{i} \cdot e^{a \cdot z_{i}}
$$

Where $t_{i}$ ' is the amplitude of the trace after applying the gain; $t_{i}$ the original amplitude of the trace; a the gain factor and $\mathrm{z}_{\mathrm{i}}$ the depth of each point of the trace. 
Thus, an objective criterion is established, based on both qualitative and quantitative analysis, in order to establish the most suitable points for drilling. The perforations are used to introduce an endoscope and illumination to visualize the cavities found in real time.

Drilling the pavement with small diameter drill $(1.2 \mathrm{~cm})$ is carried out once the position of each of the perforations has been reconsidered and then a $2 \mathrm{~cm}$ and $1 \mathrm{~m}$ long drill has been introduced (Figure 5).

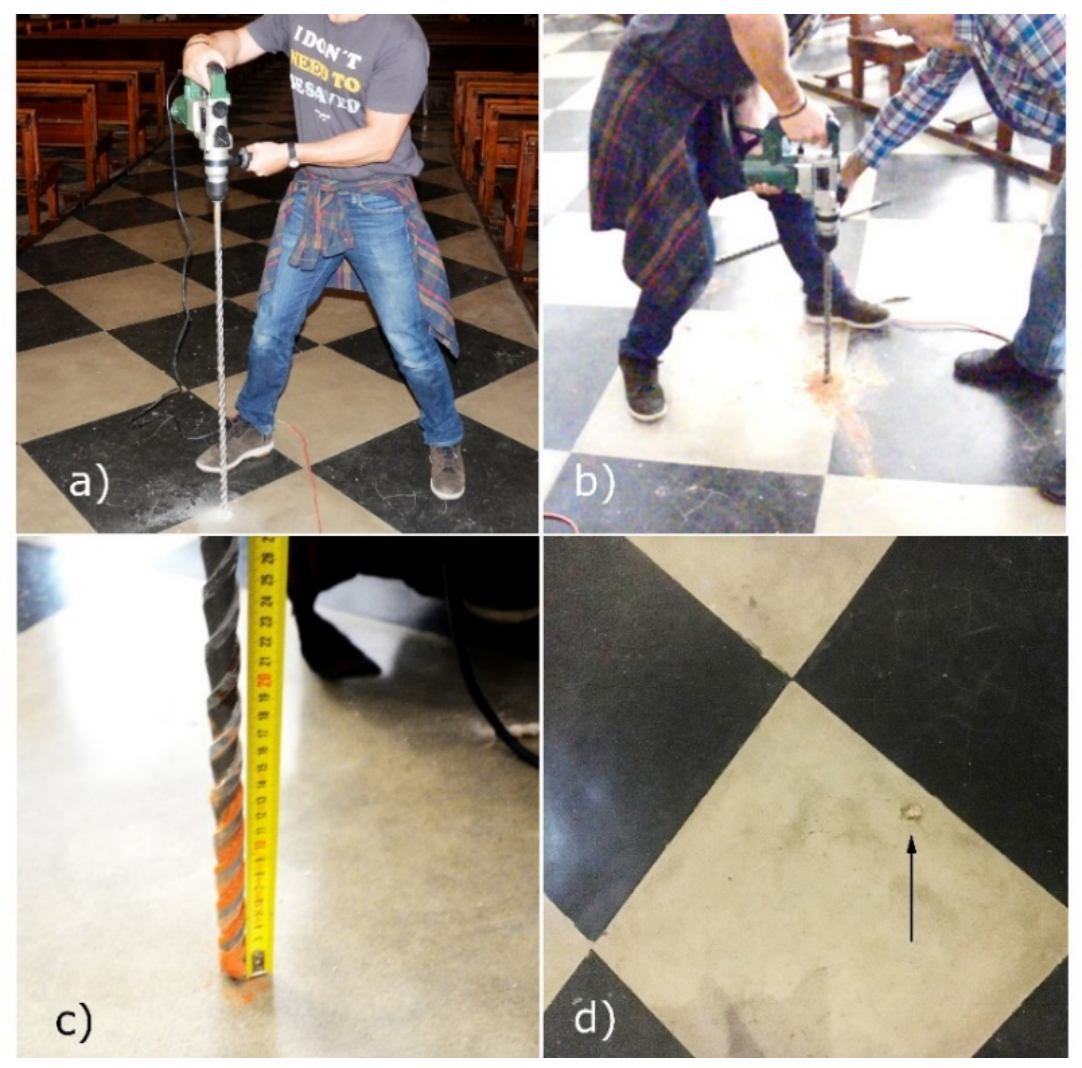

Figure 5. Drilling process in one of the identified points.

In order to verify the analyses developed with the georadar data, it is necessary to be able to compare them with reality. For this purpose, it is proposed in this work to carry out small perforations in the ground, in specific and precise places obtained thanks to the analysis of the GPR profiles, in which a small camera of photos and video is introduced. A $7 \mathrm{~mm}$ diameter USB endoscope has been used here, easy to use and with 
a very low economic cost. This endoscope was connected to a laptop in order to be able to visualize in real time through the software ViewPlayCap® [67]. In this way it is possible to capture a large number of images for further qualitative analysis and to compare them with the georadar profiles. Likewise, the endoscope itself has eight small LED lamps that illuminate totally dark spaces, although they are insufficient to illuminate by themselves a distance of more than $20 \mathrm{~cm}$ approx. For this reason, in large spaces such as buried funerary structures (crypt type), another perforation is used to illuminate with a higher-powered LED strip (Figure 6).
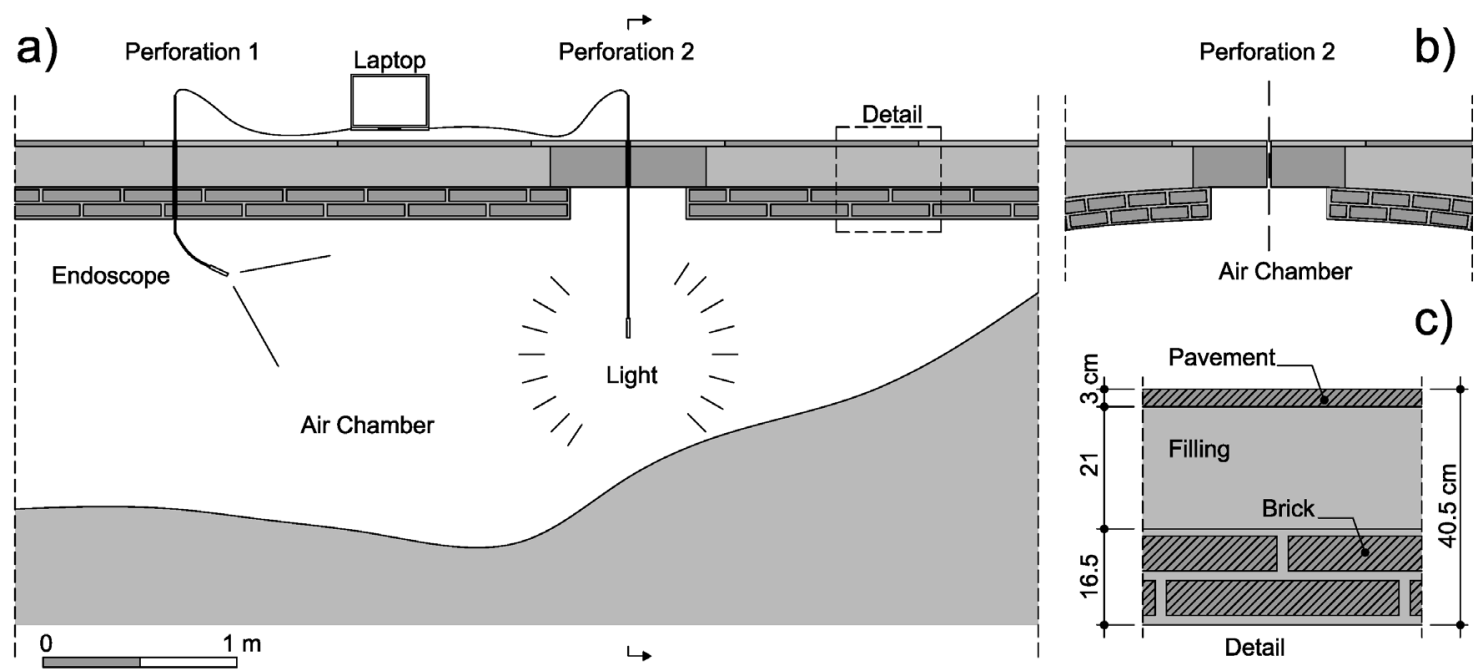

Figure 6. (a) Longitudinal section, (b) cross section and (c) detail of the vault.

\section{Results and discussion}

Figure 7 shows the GPR P1 and P2 profiles superimposed with the building floor plan, as well as the drilling campaign. Profile P1 corresponds to the central nave of the church. A crypt is clearly visible on the left side. The intensity in the amplitude of the signal is compatible with a cavity filled with air. In addition, the P1 profile on its left side can be confronted with reality, since this crypt is known and accessible. A very homogeneous pattern can be seen on the right side of the profile, which corresponds to 
rocky soil with no noticeable variations. However, it is surprising that the lines of the GPR extend on the right of the crypt for a considerable length. It should be noted that the depth dimension of the $\mathrm{P} 1$ profile is not on the same scale as the rest of the drawing, but this allows for a better qualitative analysis. The existence of the crypt next to the entrance to the temple was known, which due to its constructive characteristics corresponds to the final phase of construction of the church. However, due to its similarity with other contemporary temples, the existence of another closed crypt with a previous date of construction was suspected. Thus, the possibility of a great space in the subsoil similar to the known crypt is opened.

The P2 profile clearly shows 3 burial structures in the 4 lateral chapels. As in profile $\mathrm{P} 1$, an air cavity is compatible with the signal strength.

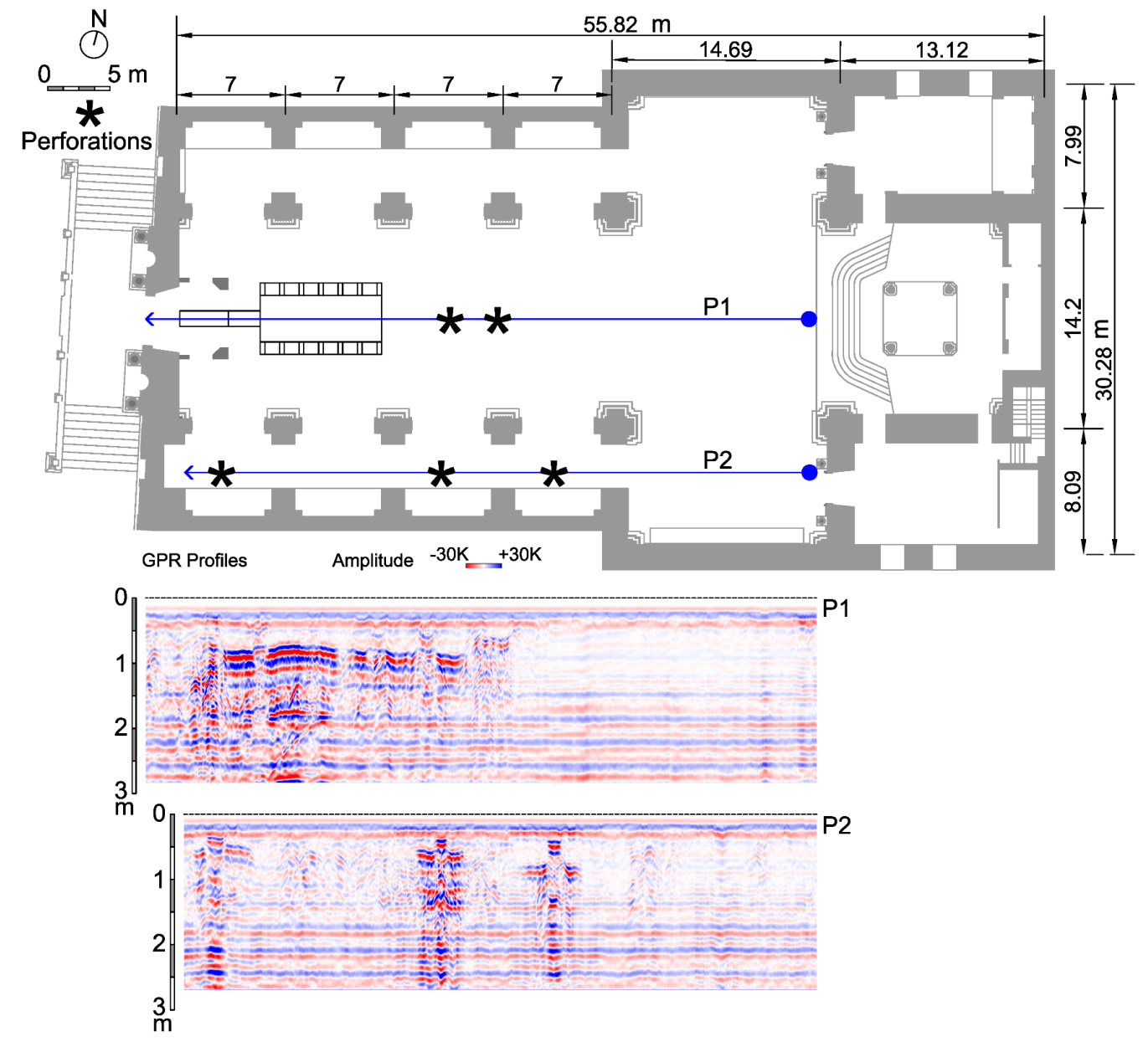

Figure 7. Plan view of the building with GPR profiles P1 and P2. 
In Figure 8, the five most remarkable GPR transverse profiles (from the church door to the altar, P6, P8, P9, P10 and P11) have been superimposed, following their position with respect to the axis of the church. Profile P6 shows on the right an irregular area of fillings. Profile P8 clearly shows the known crypt on the axis of the church. The curve reflects the curvature of the vault of the crypt, i.e. the reflection curve obtained from a cylindrical medium [68]. The P9 profile has to its left and right burials carried out in the lateral chapels. On the axis it also shows a crypt shape, although with less intensity than the $\mathrm{P} 8$ profile. The profile $\mathrm{P} 10$ and $\mathrm{P} 11$, closer to the altar, show greater homogeneity of the terrain.

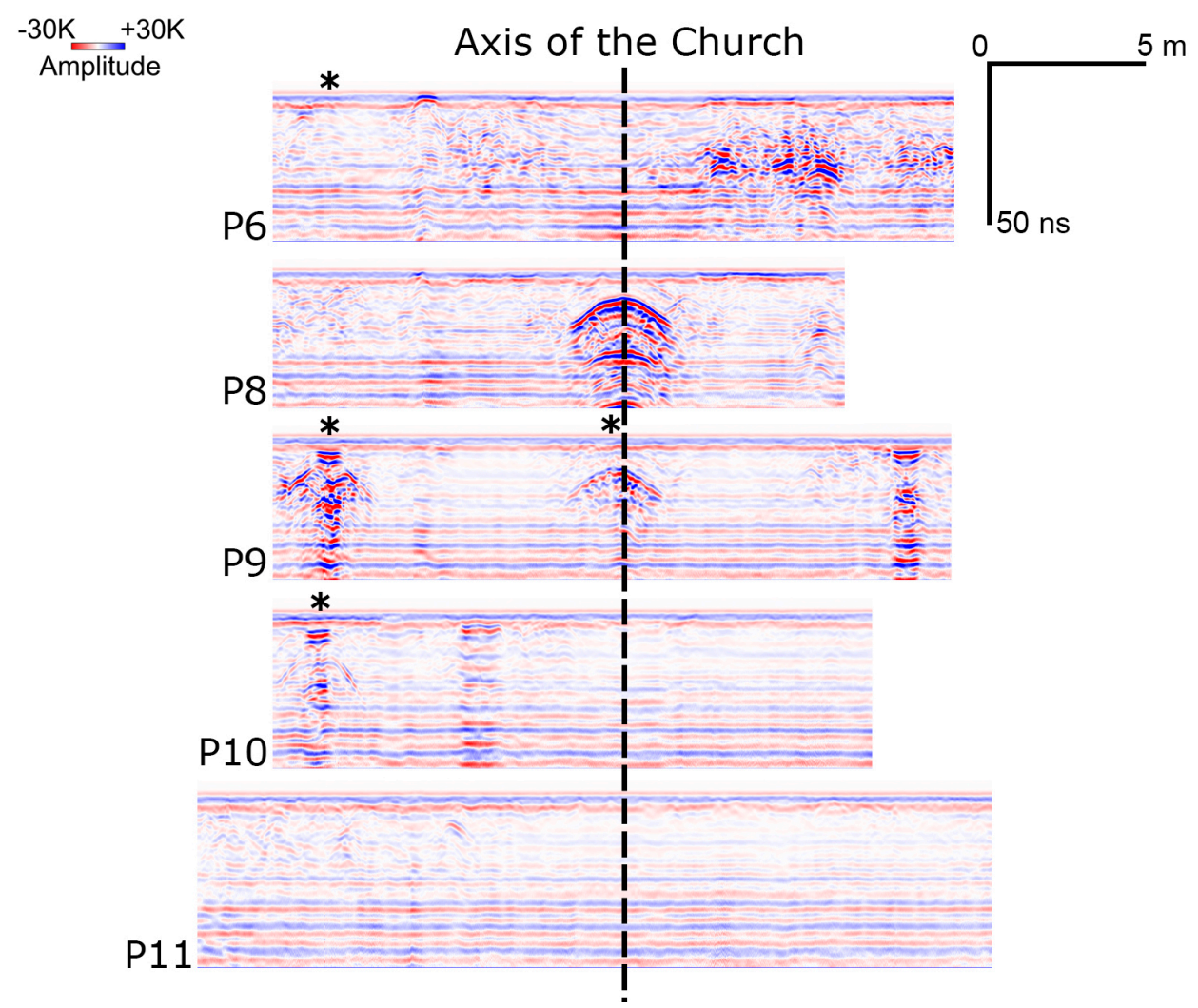

Figure 8. Transverse GPR profiles in the building. Two local reflectors are shown in P8 and P9. 


\subsection{Wave amplitude analysis techniques}

In the first analysis technique, Figure 9 shows the wavelength distribution of each of the analysed profiles using the first analysis technique. In this way, the GPR profiles in Figure 7 and Figure 8 are analysed quantitatively. In other words, the different profiles can be quantified and compared, and this allows a better decision to be made when locating the drilling points.

Amplitude data at each pixel of a GPR profile can be exported to a spreadsheet (or other calculation program such as Matlab, R, etc.). In this way, all pixels that are in each interval can be quantified or grouped together. An amplitude below 5000 does not provide much information because there are no relevant variations in the electromagnetic signal, so a filter has been established to remove them from the figure. Only 5 groups are proposed to simplify the study. A greater number of groups hides the variation pattern and with a few groups it concentrates the variation and does not allow comparison of profiles. Therefore, Figure 9 shows the pixels grouped for the amplitude intervals: 5,000-10,000; 10,000-15,000; 15,000-20,000; 20,000-25,000 and 25,00030,000 in each of the analysed profiles. Figure 9 shows each of these groups as a percentage for comparison, since the length of each GPR profile is different.

Amplitudes of $25-30 \mathrm{~K}$ close to $10 \%$ or amplitudes of $15-30 \mathrm{~K}$ close to $20 \%$ allow to identify those profiles in which perforations should be made. Figure 9 shows how profiles P10 and P11 have a low critical percentage, and other profiles such as P1, P8 or P9 clearly have the percentages proposed for drilling. 


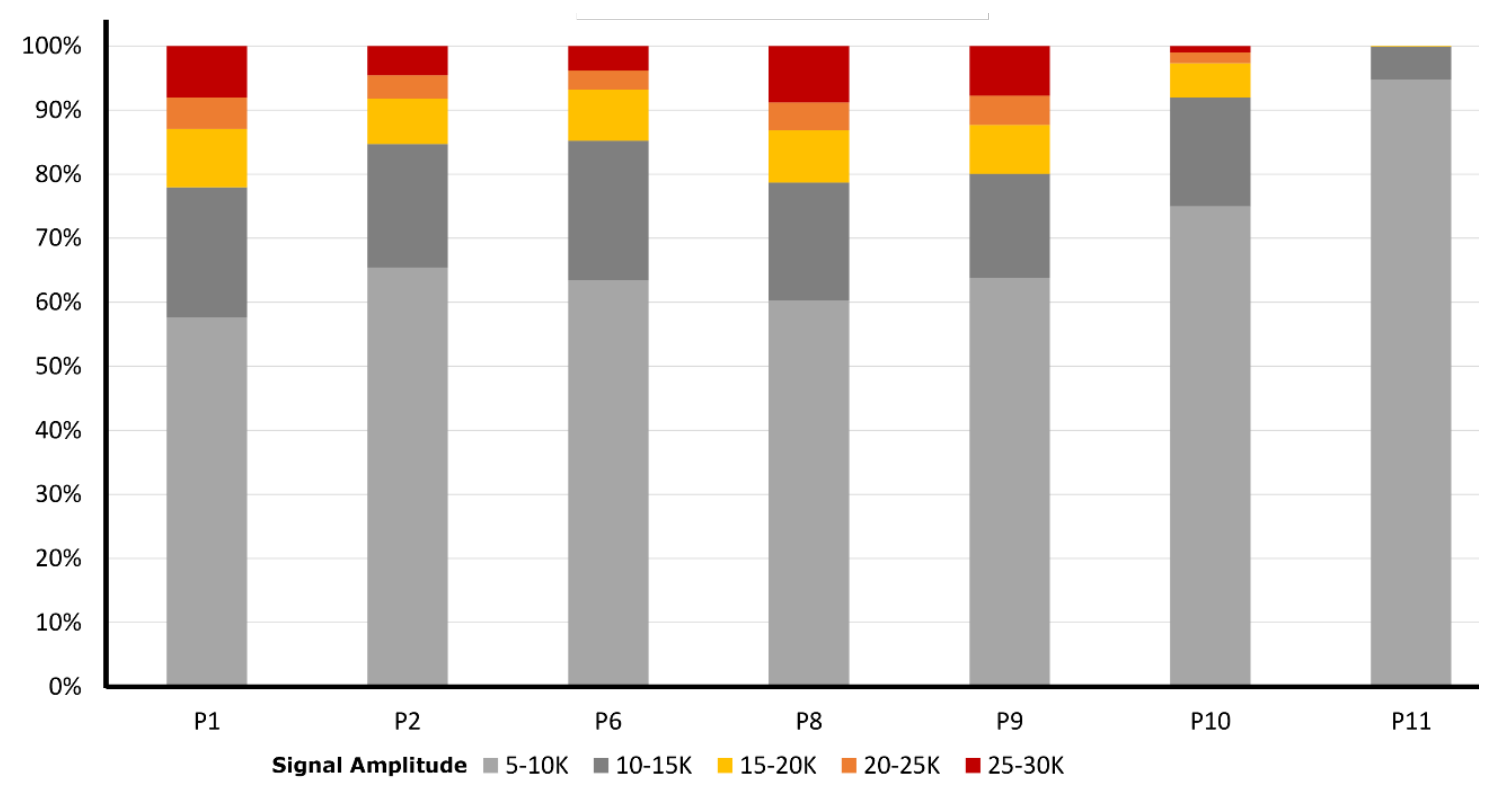

Figure 9. Distribution of Sample Amplitude of GPR.

The amplitude of the signal varies greatly when there is a change of material, for example, between solid ground and an air chamber or in the presence of groundwater. When the signal meets another material, deep reflections of the signal are produced that can distort the interpretation of the subsoil. For this reason, it is very important to determine at what depth the first large variation in signal amplitude occurs. In the second proposed analysis technique, Figure 10 shows, for each profile, the pattern at depth at which this first major change in wavelength occurs. For this purpose, the depth at which an amplitude greater than $10 \mathrm{~K}$ or less than $-10 \mathrm{~K}$ appears for the first time for the entire length of the profile has been selected. By means of the analysis of these results, those areas susceptible of being perforated are marked in yellow. Very specific changes of the depth can be discarded, as well as similar variations or following the same pattern. However, significant changes in depth in a given area indicate areas that can be drilled. 


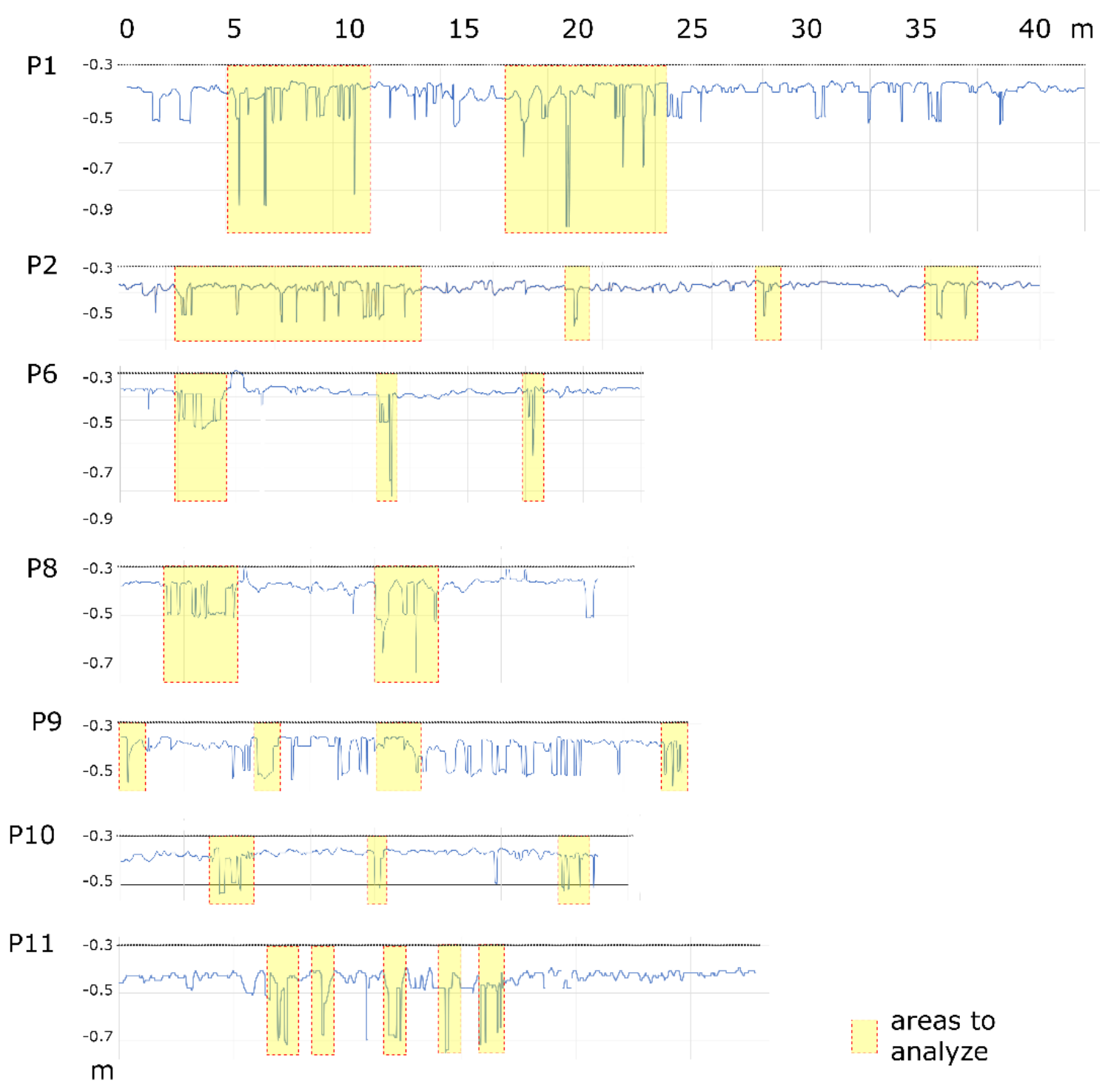

Figure 10. Depth with significant change in wave amplitude.

\subsection{Wave propagation analysis technique}

In the third analysis technique, visualizing and analysing the propagation properties of the GPR signal is possible by studying its attenuation characteristics with the MatGPR software (Figure 11). The data of Current Input Data and Output Data allow to calculate the analytical signal and, then, its instantaneous power. The program computes the median and a mean attenuation function, that is, the respective median and mean instantaneous power of all traces in the section. This allow to get some insight into the properties of the propagation medium. 
With this third technique, the best adjustment models have been determined for the power law and the exponential attenuation according to the median attenuation function. The result of this analysis (Table 3 ) allows to know the properties of the propagation medium and facilitate the gain manipulations.
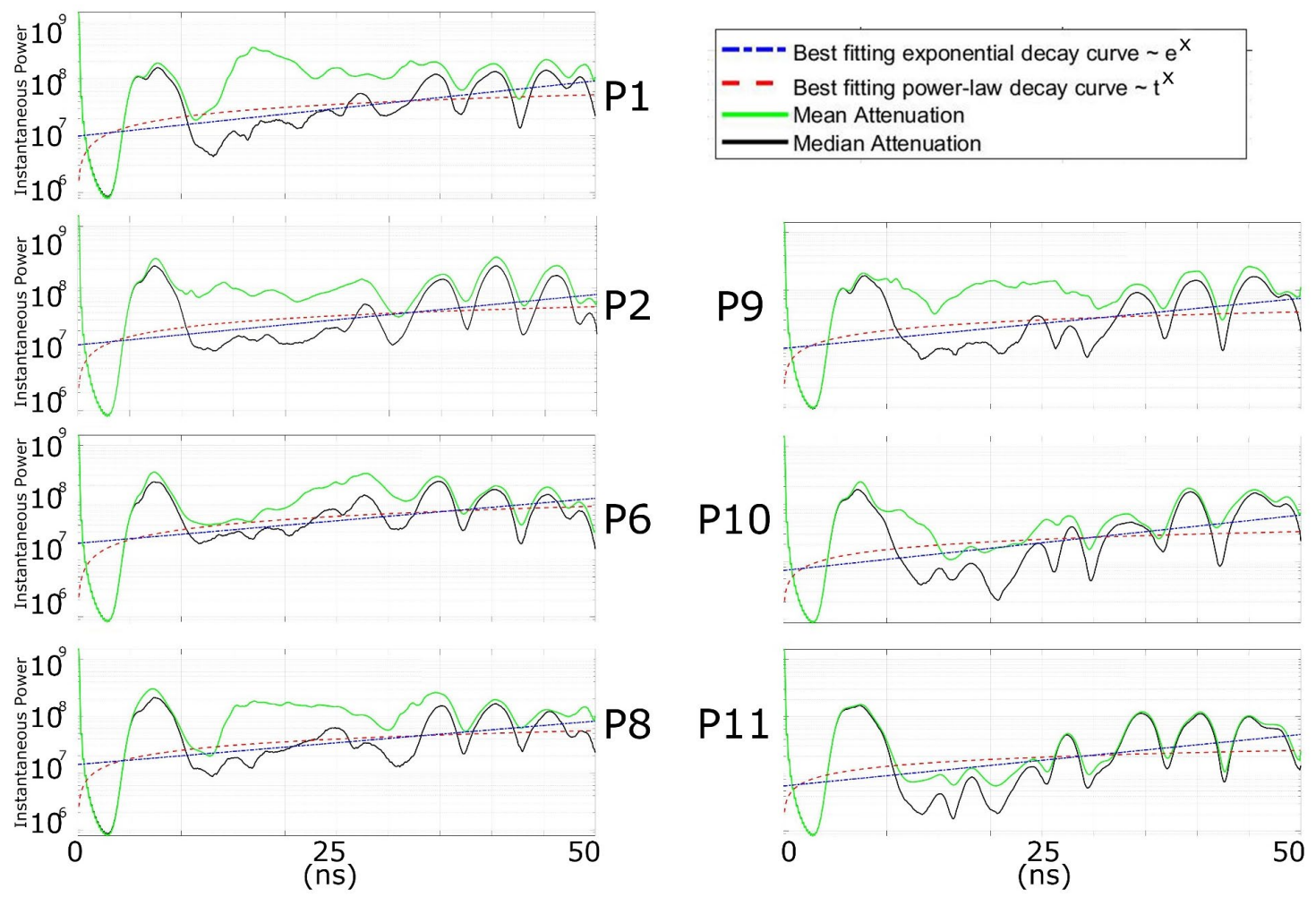

Figure 11. Attenuation characteristics of each profile.

The exponential adjustment models do not clearly reflect a relevant criterion, but the power adjustment models do in this case. Where there is a more homogeneous terrain, the exponent of $\mathrm{t}$ is smaller and, therefore, the attenuation of the signal is greater when the variation of the instantaneous power is smaller. The variation of the coefficient in the attenuation function that occurs in each profile with respect to the most homogeneous, which is $\mathrm{P} 11$, is also shown. This $\mathrm{P} 11$ profile reflects a very homogeneous stone-type terrain without significant variations. The exponential function shows that the profile P1 has a coefficient $+7.7 \%$, therefore, with less attenuation of the signal, and the profile $\mathrm{P} 8$ with $-15.4 \%$. The potential function shows how all the other 
profiles analysed have higher coefficient values, up to $+46.7 \%$ for profile $\mathrm{P} 6$, indicating that the signal attenuation is lower.

Table 3. Adjustment models of GPR signal attenuation.

\begin{tabular}{ccccc}
\hline Profile & $\begin{array}{c}\text { Best fitting } \\
\text { exponential } \\
\text { decay } \sim \mathrm{e}^{\mathrm{x}}\end{array}$ & $\begin{array}{c}\Delta \text { with respect } \\
\mathrm{P} 11\end{array}$ & $\begin{array}{c}\text { Best fitting } \\
\text { power-law decay } \\
\text { curve } \sim \mathrm{t}^{\mathrm{x}}\end{array}$ & $\begin{array}{c}\Delta \text { with respect } \\
\mathrm{P} 11\end{array}$ \\
\hline $\mathrm{P} 1$ & $\mathrm{e}^{0.0447 \cdot \mathrm{t}}$ & $+7.7 \%$ & $\mathrm{t}^{0.5606}$ & $+39.6 \%$ \\
\hline $\mathrm{P} 2$ & $\mathrm{e}^{0.0378 \cdot \mathrm{t}}$ & $-8.9 \%$ & $\mathrm{t}^{0.4879}$ & $+21.5 \%$ \\
\hline P6 & $\mathrm{e}^{0.0362 \cdot \mathrm{t}}$ & $-12.8 \%$ & $\mathrm{t}^{0.5893}$ & $+46.7 \%$ \\
\hline P8 & $\mathrm{e}^{0.0351 \cdot \mathrm{t}}$ & $-15.4 \%$ & $\mathrm{t}^{0.4953}$ & $+23.3 \%$ \\
\hline P9 & $\mathrm{e}^{0.0401 \cdot \mathrm{t}}$ & $-3.4 \%$ & $\mathrm{t}^{0.4628}$ & $+15.2 \%$ \\
\hline P10 & $\mathrm{e}^{0.0444 \cdot \mathrm{t}}$ & $+7.0 \%$ & $\mathrm{t}^{0.4473}$ & $+11.4 \%$ \\
\hline P11 & $\mathrm{e}^{0.0415 \cdot \mathrm{t}}$ & - & $\mathrm{t}^{0.4016}$ & - \\
\hline
\end{tabular}

\subsection{Signal propagation conditions technique}

A measure of the changes in signal propagation conditions is shown in the Figure 12 for the fourth analysis technique. The location of the centre of mass of the signal spectrum, as a function of time and distance, the calculation is based on an ultrahigh resolution time-frequency representation of a time series computed with the Stransform [69]. S-Transform is the application of a continuous wavelet transform (CWT) based on a moving and scalable localizing Gaussian window. This is calculated as a weighted mean of the frequencies present in the signal [66]:

$$
f_{c}=\frac{\int_{0}^{\infty} f S(f) d f}{\int_{0}^{\infty} S(f) d f}
$$

Where $f_{c}$ is the centroid function, $\mathrm{S}$ is the $\mathrm{S}$-transformation, and $\mathrm{f}$ the frequency.

The frequency of the centroid usually decreases as a function of time and there is a constant gradual downward change in cases of dispersive propagation [70]. Thus, it is shown the amplitude spectrum at each instant along a trace, computed with the Stransform [69]. Sudden colour changes (attenuation) should be analysed. Figure 12 complements the qualitative analysis of GPR profiles. 

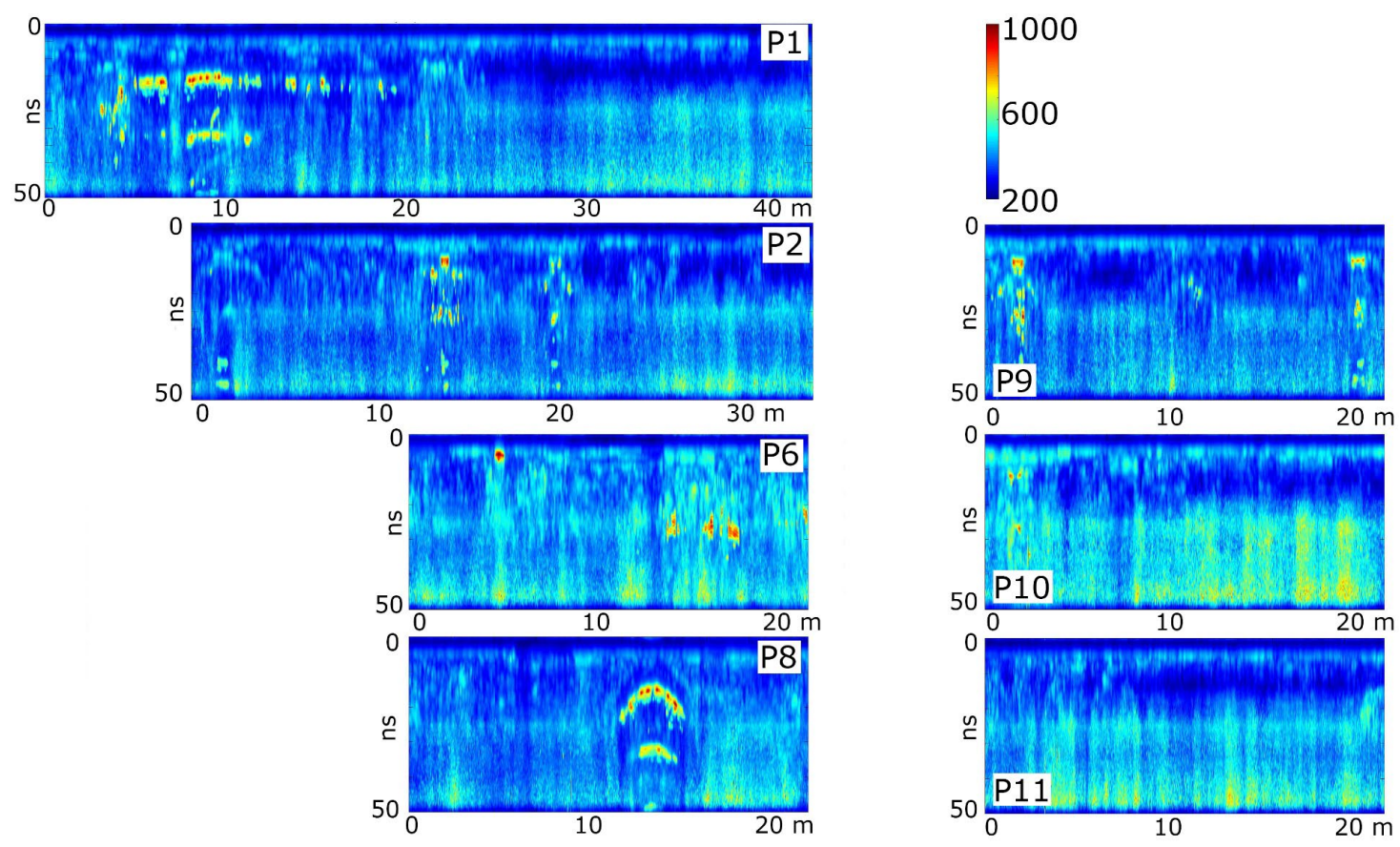

Figure 12. Centroid frequency of each profile.

The areas in which drilling is required to verify the existence of spaces or funerary structures under the pavement have been determined based on this qualitative and quantitative analysis of the GPR signal. These drilling points are shown in Figure 7 and Figure 8. Once the drilling points were decided, the endoscopic technique was applied. Figure 5 shows how the pavement was drilled directly, choosing where it was deteriorated or with some imperfection, always within the scope delimited by the GPR profiles. First, a small diameter drill was used to facilitate the penetration of a second drill with a diameter of $2 \mathrm{~cm}$ and a length of 1 meter. Two perforations are made where an endoscope, which incorporates a LED bulb, is inserted. This allows to see the inside of the illuminated crypt and to establish its shape and dimensions.

Figure 13 shows the steps for visualizing buried structures after drilling in the ground. Figure 13-a shows how the images transmitted by the endoscope are visualized in real time by means of a computer. Figure 13-b shows the perforation made in the first few cm up to the underground air chamber. Figure 13-c shows the vault of the crypt, 
with a double sheet of brick, partially fallen. Figure 13-d shows remains of bricks and debris. Some hole indicators have also been found that could correspond to burials in the subsoil of the side chapels (Figures 13-e and 13-f). This is an unknown crypt at the moment. The entrance to the crypt must have been closed with a marble slab and then covered by the floor. This crypt could correspond to the one typologically built under the altar in most churches and monasteries.

This crypt is displaced towards the central part of the church and is not found next to the main altar. The presbytery is based on rock and it was decided not to excavate in this area. This crypt was impracticable and blinded when placing the floor of the building. This primitive crypt is older than the known one and located next to the main door.

The height of the crypt decreases near the altar, just as the georadar shows, which could indicate that the staircase was located facing the altar.

The crypt corresponds to a type of living room or nave. Its composition, adapted to temples with a battery-apse head, was better suited to smaller buildings, even those with a single head, which allowed the construction of more humble crypts in rural areas [62]. It has a surface corresponding to a rectangular room that is about 5 or 6 metres long by about two metres deep. Today it is partially blinded by rubble. In its niches appear half a metre deep under stone arches. The ceiling is a barrel vault and the masonry walls of stones and mortar, as proven by the endoscope technique. It must have two rows of graves given its height.

The knowledge of these burials is very interesting for the history of the building and gives it an added value. In some cases, the restitution of the crypt has been reconsidered, as in the case of the Monastery of Ripoll [71]. 


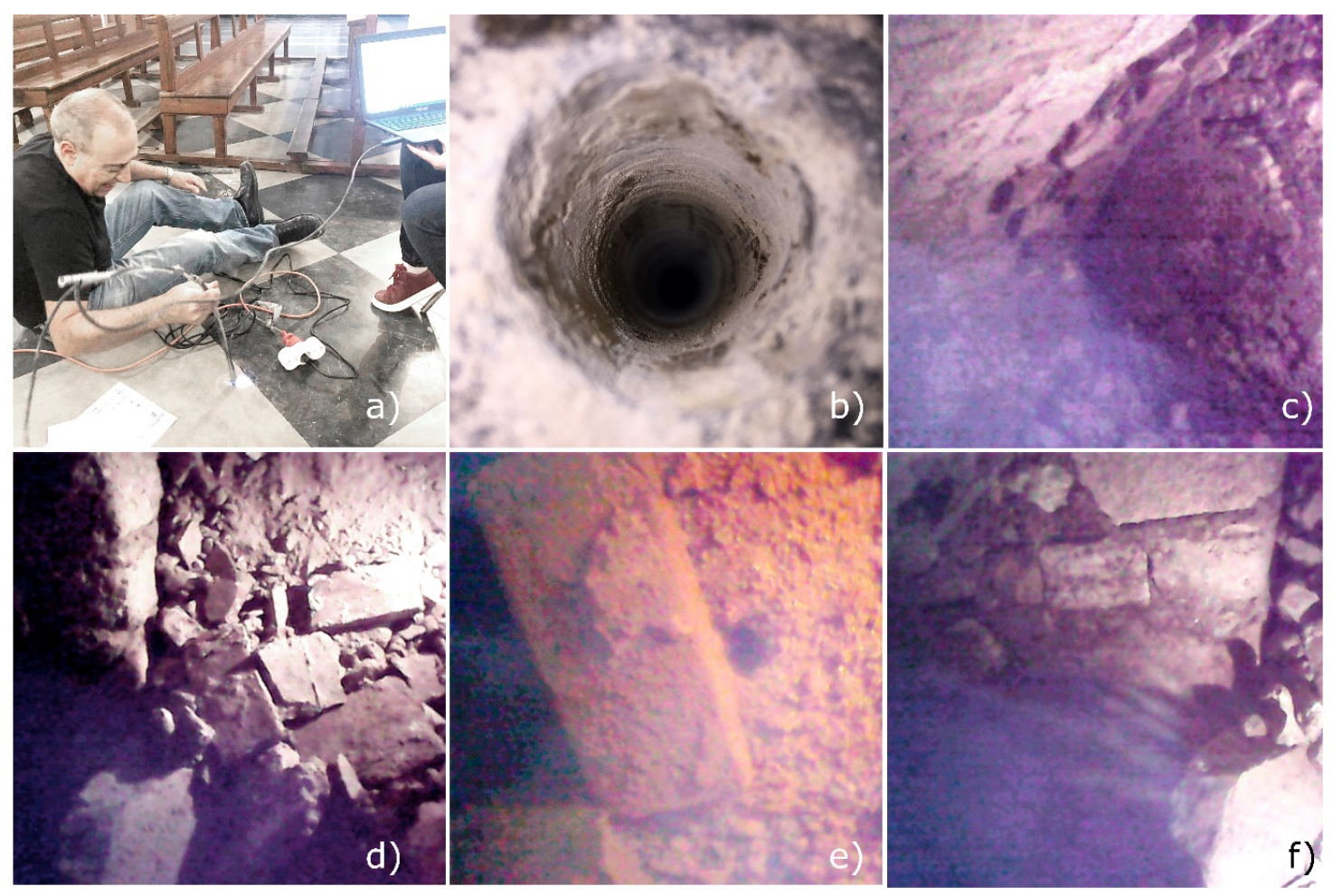

Figure 13. Visualization of buried structures by means of an economic endoscope. (a)

Viewing the endoscope with a laptop; (b) Perforation; (c) Vault of the crypt; (d)

Remains of bricks and debris; (e) Detail of arch; (f) Hole indicators.

\section{Conclusions}

The results obtained in this work confirm that the proposed methodologies are effective in seeking and confirming the location of structures buried under heritage buildings, which was a priority objective. These NDT techniques also allow to know the materials and to interpret the constructive processes that form these buried elements. For the development of the proposed methodologies, the Church of the Assumption in Llíria (Valencia, Spain) has been used.

A qualitative and quantitative approximation of the GPR profiles is necessary to decide which are the most interesting or susceptible points to locate these buried 
structures. To confirm and study possible voids, perforations are made through which an endoscope is inserted to record images.

This study uses four techniques of quantitative analysis of GPR profiles to complement the qualitative evaluation. In the first analysis technique, the signal amplitude is studied and quantified for each of the GPR profiles. It is considered that $25-30 \mathrm{~K}$ amplitudes close to $10 \%$ or $15-30 \mathrm{~K}$ amplitudes close to $20 \%$ allow to identify the profiles in which a further study with drilling is more interesting.

The second analysis technique states that the depth at which the first large variation in signal amplitude occurs allows to establish patterns for each profile and to determine those areas that behave differently and are susceptible to more specific analysis.

The variation of the adjustment models in the attenuation of the GPR signal is also evaluated in the third technique, being the power-law model more efficient than the exponential one in this case. The power-law model fits better and indicates positive increases in the coefficient of this function, up to $+46.7 \%$ for the P6 profile. Where the terrain is more homogeneous, the exponent of $\mathrm{t}$ is smaller and, therefore, the attenuation of the signal is greater. In this way, it is interesting to continue with the research of profiles with greater exponent.

Finally, in the fourth technique some software filters are used to measure the changes in signal propagation conditions.

The areas in which drilling is required to verify the existence of spaces or funerary structures under the pavement have been determined based on this qualitative and quantitative analysis of the GPR signal.

An archaeological excavation implies a great deployment of means, interrupting the habitual use of the building, as well as a great economic investment and time to be 
able to carry out the intervention. For this reason, the analysis of the georadar profiles and the confirmation by using an endoscope, which is introduced through small perforations made in the ground, is proposed as an alternative. Table 4 presents a summary of advantages and disadvantages of the techniques used.

Table 4. Summary of the advantages and disadvantages of the techniques used.

\begin{tabular}{|c|c|c|c|}
\hline Study & $\begin{array}{l}\text { Analysis } \\
\text { Technique }\end{array}$ & Advantages & Disadvantages \\
\hline \multirow{2}{*}{$\begin{array}{c}\text { GPR } \\
\text { Wave amplitude } \\
\text { analysis techniques }\end{array}$} & 1 st & $\begin{array}{l}\text { - Easy to compute. } \\
\text { - Easy to compare } \\
\text { between profiles. }\end{array}$ & - Generic data. \\
\hline & 2nd & $\begin{array}{l}\text { - Large study area. } \\
\text { - High information } \\
\text { accuracy. }\end{array}$ & - Variable data. \\
\hline $\begin{array}{c}\text { GPR } \\
\text { Wave propagation } \\
\text { analysis technique }\end{array}$ & $3 \mathrm{rd}$ & $\begin{array}{l}\text { - High information } \\
\text { accuracy. }\end{array}$ & $\begin{array}{l}\text { - Generic and global data } \\
\text { of each profile. }\end{array}$ \\
\hline $\begin{array}{c}\text { GPR } \\
\text { Signal propagation } \\
\text { conditions technique }\end{array}$ & 4th & $\begin{array}{l}\text { - High information } \\
\text { accuracy. }\end{array}$ & $\begin{array}{l}\text { - Requires qualitative } \\
\text { analysis. }\end{array}$ \\
\hline Endoscope & & $\begin{array}{l}\text { - Minimal intrusive } \\
\text { technique. }\end{array}$ & $\begin{array}{l}\text { - Requires drilling. } \\
\text { - Local study. }\end{array}$ \\
\hline
\end{tabular}

The results of this work allow a step forward in the knowledge of applying NDT techniques for the knowledge of the building materials which compose ancient structures buried under heritage buildings. The least possible damage caused to the building is possible through these methodologies. Likewise, previously unknown valuable information was revealed in the Church of the Assumption in Llíria (Valencia, Spain), such as a crypt attached to another well-known crypt and other funerary structures in some of the side chapels of the church.

This study highlighted the importance of discovering these elements to increase the knowledge of cultural heritage, as well as to know and improve the state of conservation of the materials which constitute these structures. It shows a new research methodology to detect sites where it is interesting and profitable to carry out an archaeological campaign. This is done by means of NDT that suppose a minimum 
impact in the heritage building and a very reduced economic cost and time that helps to decide on the convenience of proceeding to recover the crypt as an element of conservation of architectural heritage.

While the study focused on non-destructive techniques methodologies for the detection of ancient structures under heritage buildings the results clearly indicate the versatility and potential of the proposed methodology and new tools are presented for further general applications in other similar or more complex case studies.

Concerning future research, the visualization of GPR profiles into time slices would facilitate the use of quantitative analyses as prediction instrument and it is useful for an archaeological interpretation.

\section{References}

[1] D. Ranalli, M. Scozzafava, M. Tallini. Ground penetrating radar investigations for the restoration of historic buildings: the case study of the Collemaggio Basilica (L'Aquila, Italy). Journal of Cultural Heritage, 5, pp. 91-99, 2004. https://doi.org/10.1016/j.culher.2003.05.001.

[2] N. Masini, L. Nuzzo, E. Rizzo. GPR investigations for the study and the restoration of the rose window of Troia Cathedral (southern Italy). Near Surface Geophysics, 5(5), pp. 287-300, 2007. http://dx.doi.org/10.3997/1873-0604.2007010.

[3] García-Diego, F.J., Esteban, B., Merello, P. Design of a Hybrid (Wired/Wireless) Acquisition Data System for Monitoring of Cultural Heritage Physical Parameters in Smart Cities. Sensors, Vol 15, Issue 4, 7246-7266, 2015. http://dx.doi.org/10.3390/s150407246.

[4] Gil, E., Lerma, C., Vercher, J., Mas, Á. (2017). Methodology for thermal behaviour assessment of homogeneous façades in heritage buildings. Journal of Sensors, vol. 2017, Hindawi, 2017, p. 13, https://doi.org/10.1155/2017/3280691.

[5] Calia, A., Leucci, G., Nicola, M., Matera, L., Persico, R., and Sileo, M. Integrated prospecting in the crypt of the Basilica of Saint Nicholas in Bari, Italy. J. Geophys. Eng., 9, 1-11, 2012. https://doi.org/10.1088/1742-2132/9/3/271.

[6] Carlomagno, G. M., Di Maio, R., Fedi, M., and Meola, C. Integration of infrared thermography and high-frequency electromagnetic methods in archaeological surveys. J. Geophys. Eng., 8, S93 pp., 2011. https://doi.org/10.1088/1742-2132/8/3/S09. 
[7] Grinzato, E., Bison, P. G., and Marinetti, S.: Monitoring of ancient buildings by the thermal method, J. Cult. Herit., 3 (2002), 21-29, http://dx.doi.org/10.1016/S12962074(02)01159-7.

[8] Masini, N., Persico, R., and Rizzo, E. Some Examples of GPR Prospecting for Monitoring of the Monumental Heritage. J. Geophys. Eng., 7 (2010), 190-199, http://dx.doi.org/10.1088/1742-2132/7/2/S05.

[9] Sánchez-Aparicio, L.J., Bautista-De Castro, Á., Conde, B., Carrasco, P., Ramos, L.F. (2019). Non-destructive means and methods for structural diagnosis of masonry arch bridges. Automation in Construction, Volume 104, 360-382 https://doi.org/10.1016/j.autcon.2019.04.021.

[10] Barone, P. M., Di Matteo, A., Graziano, F., Mattei, E., \& Pettinelli, E. (2010). GPR Application to the structural control of historical buildings: two case studies in Rome, Italy. Near Surface Geophysics, 8(5), 407-414. http://dx.doi.org/0.3997/1873$\underline{0604.2010017 .}$

[11] Bavusi, M., Soldovieri, F., Piscitelli, S., Loperte, A., Vallianatos, F., \& Soupios, P. (2010). Ground penetrating radar and microwave tomography to evaluate the crack and joint geometry in historical buildings: some examples from Chania, Crete, Greece. Near Surface Geophysics, 8(5), 377-388. http://dx.doi.org/10.3997/1873-0604.2010039.

[12] Lorenzo, H., Hernández, M. C., \& Cuéllar, V. (2002). Selected Radar Images of Man-Made Underground Galleries. Archaeological Prospection, 9(1), 1-8. https://doi.org/10.1002/arp.174.

[13] Aguilar, R., Noel, M. F., Ramos, L. F. (2019). Integration of reverse engineering and non-linear numerical analysis for the seismic assessment of historical adobe buildings. Automation in Construction, Volume 98, 1-15. https://doi.org/10.1016/j.autcon.2018.11.010.

[14] Arce, Á., Ramos, L. F., Fernandes, F. M., Sánchez-Aparicio, L. J. \& Lourenço P. B. (2018). Integrated structural safety analysis of San Francisco Master Gate in the Fortress of Almeida, International Journal of Architectural Heritage, 12:5, 761-778. https://dx.doi.org/10.1080/15583058.2017.1370507.

[15] Lerma, C., Barreira, E., \& Almeida, RMSF. (2018). A discussion concerning active infrared thermography in the evaluation of buildings air infiltration. Energy \& Buildings, 168, 56-66. https://doi.org/10.1016/j.enbuild.2018.02.050.

[16] Lerma, C., Mas, Á, Gil, E., Vercher, J., \& Peñalver, M. J. (2014). Pathology of Building Materials in Historic Buildings. Relationship Between Laboratory Testing and Infrared Thermography. Materiales de Construccion, 64 (313). https://doi.org/10.3989/mc.2013.06612.

[17] Masini N., Persico R., Rizzo E., Calia A, Giannotta MT, Quarta G, Pagliuca A. (2010). Integrated Techniques for Analysis and Monitoring of Historical Monuments: the case of S. Giovanni al Sepolcro in Brindisi (Southern Italy), Near Surface Geophysics, 8(5), 423-432. https://dx.doi.org/10.3997/1873-0604.2010012. 
[18] Alexakis, E., Delegou, E.T., Lampropoulos, K.C., Apostolopoulou, M., Ntoutsi, I., Moropoulou, A. (2018). NDT as a monitoring tool of the works progress and the assessment of materials and rehabilitation interventions at the Holy Aedicule of the Holy Sepulchre. Construction and Building Materials. Volume 189, 512-526. https://doi.org/10.1016/j.conbuildmat.2018.09.007.

[19] Arêde, A., Almeida, C., Costa, C. Costa, Á. (2019). In-situ and lab tests for mechanical characterization of stone masonry historical structures. Construction and Building Materials, Volume 220, 503-515. https://doi.org/10.1016/j.conbuildmat.2019.06.039.

[20] Cardarelli, E., Fischanger, F., and Piro, S. Integrated geophysical survey to detect buried structures for archaeological prospecting. A case-history at Sabine Necropolis (Rome, Italy). Near Surf. Geophys., 6, 15-20, 2008. http://dx.doi.org/10.3997/1873$\underline{0604.2007027 .}$.

[21] Goodman, D. and Piro, S.: GPR Remote sensing in Archaeology, Springer (Ed), ISBN: 978-3-642-31856-6, ISBN: 978-3-642-31857-3 (eBook), doi:10.1007/978-3-64231857-3, Springer, Berlin, Germany, 2013.

[22] Persico, R., Ciminale, M., and Matera, L. A new reconfigurable stepped frequency GPR system, possibilities and issues; applications to two different Cultural Heritage Resources. Near Surf. Geophys., 12, 793-801, 2014. http://dx.doi.org/10.3997/1873$\underline{0604.2014035 .}$.

[23] Piscitelli, S., Rizzo, E., Cristallo, F., Lapenna, V., Crocco, L., Persico, R., and Soldovieri, F. GPR and microwave tomography for detecting shallow cavities in the historical area of Sassi of Matera (Southern Italy). Near Surf. Geophys., 5 (2007), 275284, http://dx.doi.org10.3997/1873-0604.2007009.

[24] Utsi EC, Colls KS. The GPR Investigation of the Shakespeare Family Graves. Archaeological Prospection. 2017; 24:335-352. https://doi.org/10.1002/arp.1573

[25] Maki, D. \& Fields, R. C. (2010). Multisensor geophysical survey results from the pine tree mound site: a comparison of geophysical and excavation data. Southeastern Archaeology, 29:2, 292-309, https://dx.doi.org/10.1179/sea.2010.29.2.006.

[26] Morris, I.; Cleary, J.; Gonciar, A.; Glisic, B. (2019). Ground Penetrating Radar Investigation of Corvin Castle (Castelul Corvinilor), Hunedoara, Romania. Heritage, 2, 1316-1349. https://doi.org/10.3390/heritage2020085.

[27] Piro, S., Ceraudo, G., Zamuner, D. (2011). Integrated geophysical and archaeological investigations of aquinum in Frosinone, Italy, Archaeological Prospection Volume 18, Issue 2, Pages 127-138. https://doi.org/10.1002/arp.409.

[28] Masini N., Capozzoli L., Chen P., Chen F., Romano G.,Lu P., Tang P., Sileo M., Ge Q., Lasaponara R. (2017). Towards an operational use of geophysics for Archaeology in Henan (China): Archaeogeophysical investigations, approach and results in Kaifeng. Remote Sensing 9 (8), 809. http://dx.doi.org/10.3390/rs9080809. 
[29] Forte, E., Pipan, M. (2017). Review of multi-offset GPR applications: Data acquisition, processing and analysis. Signal Processing 132, 210-220.

http://dx.doi.org/10.1016/j.sigpro.2016.04.011.

[30] Zhao, Shan, \& Al-Qadi, Imad L. (2018). Continuous real-time monitoring of flexible pavement layer density and thickness using ground penetrating radar. NDT \& E International, 100, 48-54. https://doi.org/10.1016/j.ndteint.2018.08.005.

[31] Gucunski, Nenad, \& Zayed, Tarek. (2019). Automated visualization of concrete bridge deck condition from GPR data. NDT \& E International, 102, 120-128.

https://doi.org/10.1016/j.ndteint.2018.11.015.

[32] L.B. Conyers, Innovative ground-penetrating radar methods for archaeological mapping. Archaeological Prospection. 13, pp. 139-141, 2006.

https://doi.org/10.1002/arp.282.

[33] G. Barone, C. Branca, S. Gresta, S. Imposa, A. Leone, D. Majolino, Geoarcheometric and geophysical methodologies applied to the study of cultural heritage: "St. Agata la Vetere" in Catania (Sicily, Italy). Journal of Cultural Heritage, 5, pp. 263-271, 2004. https://doi.org/10.1016/j.culher.2004.01.002.

[34] M. De la Vega, A. Osella, E. Lascano, J.M. Carcione. Ground penetrating radar and geo-electrical simulations of data from the Floridablanca archaeological site. Archaeological Prospection, 12, pp. 19-30, 2005. http://dx.doi.org/10.1002/arp.244.

[35] V.P. Gracia, J.A. Canas, L.G. Pujades, J. Clap s, O. Caselles, F. Garc a, R. Osorio. GPR survey to confirm the location of ancient structures under the Valencian Cathedral (Spain). Journal of Applied Geophysics, 43(2), pp. 167-174, 2000.

http://dx.doi.org/10.1016/S0926-9851(99)00056-7.

[36] Conyers L.B. (2015). Analysis and interpretation of GPR datasets for integrated archaeological mapping, Near Surface Geophysics Volume 13, Issue 6, Pages 645-651. https://dx.doi.org/10.3997/1873-0604.2015018.

[37] Matera L, Persico R, Geraldi E, Sileo M, Piro S. (2016). GPR and IRT tests in two historical buildings in Gravina in Puglia, Geoscientific Instrumentation, Methods and Data Systems Open Access, Volume 5, Issue 2, 29 November 2016, Pages 541-550. https://dx.doi.org/10.5194/gi-5-541-2016.

[38] Grassi, Sabrina, Di Raimondo, Saro, Patti, Graziano, \& Lombardo, Giuseppe. (2018). Seismic refraction tomography surveys as a method for voids detection: an application to the archaeological park of Cava Ispica, Sicily, Italy. INTERNATIONAL JOURNAL OF ARCHITECTURAL HERITAGE, 12(5), 806-815. https://doi.org/10.1080/15583058.2017.1419311.

[39] Persico R. (2016). Introduction to Ground Penetrating Radar: Inverse Scattering and Data Processing. Wiley-IEEE Press. ISBN: 978-1-118-30500-3.

[40] Solla, Lorenzo, Rial, \& Novo. (2012). Ground-penetrating radar for the structural evaluation of masonry bridges: Results and interpretational tools. Construction and Building Materials, 29, 458-465. https://doi.org/10.1016/j.conbuildmat.2011.10.001. 
[41] Conyers L.B. (2016). Ground-penetrating Radar for Geoarchaeology, Groundpenetrating Radar for Geoarchaeology, Pages 1-147.

https://dx.doi.org/10.1002/9781118949993.

[42] García, A. (2012). La topografía funeraria del monasterio de Corias en la época medieval a partir de la arqueología y las fuentes escritas Territorio, Sociedad y Poder. Revista de estudios medievales 7, 129-178.

https://www.unioviedo.es/arqueologiamedieval/index archivos/Articulos_Alex/Corias Topografia_funeraria_TSP_2012.pdf.

[43] Pulido-Castillo, G. (2006) Cemeteries and crypts of Huéscar. Burial places since 1488. Boletín del Centro de Estudios Pedro Suárez, 19, 11-

58.http://cepedrosuarez.es/docs/boletines/B19_2006 01_PULIDO.pdf.

[44] Morais-Vallejo, E. (1998). La cripta funeraria de los marqueses de Astorga. Estudios Humanísticos, 20, 203-218. http://hdl.handle.net/10612/2120.

[45] Martínez-Álava, C.J. (2008). Los espacios subterráneos: la función tectónica y litúrgica de las criptas románicas Espacios y estructuras singulares del edificio románico. ISBN 978-84-89483-50-7.

[46] Petrickova, M., \& Joja, M. (2016). Interpretation of traditional structural principles in contemporary architecture. 8TH Architektura V Perspektiv. Ostrava: Ostrava Technical University. ISBN: 978-80-248-3940-0.

[47] Bérchez, J. (1993). Arquitectura barroca valenciana. Valencia: Bancaja. ISBN: 978-84-87684-38-8.

[48] Domingo, A. (1996). La crisis Del Siglo XVII: la población, la economía, la sociedad. Madrid: Espasa Calpe. ISBN: 978-84-239-4994-6.

[49] Juan, F. (2006). Valor barroco en la arquitectura valencia. General de Ediciones de Arquitectura. D.L. ISBN: 9788493516338.

[50] Torner, M.E. (2015). Sistemas de análisis mediante la aplicación de nuevas herramientas al estudio morfológico constructivo de la iglesia de Nuestra Señora de la Asunción. PhD Thesis. Valencia: Universidad Cardenal Herrera-CEU. http://dspace.ceu.es/handle/10637/7387.

[51] Pace, S. (2014). History of urbanism in Spain, vol. 2, Centuries XVI, XVII and XVIII. Planning Perspectives, 29 (1). http://dx.doi.org/10.1080/02665433.2013.860824.

[52] Loseby, ST. (2011). Reflections on urban space: streets through time. Reti Medieval Rivista, 3. https://core.ac.uk/download/pdf/141654837.pdf.

[53] Torner, M.E, Mas, A., Lerma, C., \& Gil, E. (2015). Metodología para el estudio de las trazas y las relaciones intrínsecas en la Iglesia de la Asunción de Llíria. Informes de la construcción, 67 (538), e070. http://dx.doi.org/10.3989/ic.13.118.

[54] Pingarrón Seco, F. (1995). Las advertencias para los edificios y fábricas de los templos del sínodo del arzobispo de Valencia Isidoro Aliaga en 1631: Estudio y transcripción. Valencia. ISBN: 978-84-605-3431-0. 
[55] L. Martí. Historia de la muy ilustre ciudad de Liria. Ed. Soc. Cult. De Liria, Valencia, 1986. ISBN 8439873204.

[56] Büttner, S., 2014. L'analyse des liants de maçonnerie et son apport à la comprehension chronologique et technique de la construction. In: Bolle, C., Coura, C., Léotard, J.M. (Eds.), L'archéologie des Bâtiments en Question. Un Outil Pour les Connaitre, les Conserver et les Restaurer, Actes du Colloque International, Liège, 910/11/2010, Namur (Études et Documents, Archéologie, 35), pp. 103-114 (390p). http://refhub.elsevier.com/S2352-409X(17)30705-8/rf0050.

[57] Carò, F., Riccardi, M.P., Mazzilli Savini, M.T., 2008. Characterization of plasters and mortars as a tool in archaeological studies: the case of Lardirago castle in Pavia, Northern Italy. Archaeometry 50, 85-100. http://dx.doi.org/10.1111/j.1475$\underline{\text { 4754.2007.00337.x. }}$

[58] Chiarelli, N., Miriello, D., Bianchi, G., Fichera, G., Giamello, M., Turbanti Memmia, I., 2015. Characterisation of ancient mortars from the S. Niccolò archaeological complex in Montieri (Tuscany - Italy). Constr. Build. Mater. 96, 442460. https://doi.org/10.1016/j.conbuildmat.2015.08.023.

[59] De Luca, R., Cau Ontiveros, M.A., Miriello, D., Pecci, A., Le Pera, E., 2013. Archaeometric study of mortars and plasters from the Roman City of Pollentia (Mallorca-Balearic Islands). Periodico di Mineralogia 82 (3), 353-379. http://dx.doi.org/10.2451/2013PM0021.

[60] Frizot, M., 1975. Mortiers et enduits peints antiques. Université Dijon, Etude technique et archéologique. Centre des recherches sur les techniques gréco-romains. http://refhub.elsevier.com/S2352-409X(17)30705-8/rf0115.

[61] Furlan, V., Bissenger, P., 1975. Les mortiers anciens, histoire et essais d'analyse scientifique. In: Revue Suisse d'Art et d'Archéologie, pp. 166-178. http://refhub.elsevier.com/S2352-409X(17)30705-8/rf0120.

[62] Miriello, D., Barca, D., Bloise, A., Ciarallo, A., Crisci, G.M., 2010.

Characterization of archaeological mortars from Pompeii (Campania, Italy) and identification of construction phases by compositional data analysis. J. Archaeol. Sci. 37, 2207-2223. https://doi.org/10.1016/j.jas.2010.03.019.

[63] Sanjurjo-Sánchez, J., Trindade, M.J., Blanco-Rotea, R., Benavides Garcia, R., Fernández Mosquera, D., Burbidge, C., Prudêncio, M.I., Dias, M.I., 2010. Chemical and mineralogical characterization of historic mortars from the Santa Eulalia de Bóveda temple, NW Spain. J. Archaeol. Sci. 37, 2346-2351. https://doi.org/10.1016/j.jas.2010.04.008.

[64] Cristini, V. Brick mansonry in Valencia: mensiochronological analysis and finishing techniques (17-18th centuries). Arqueología de la arquitectura, 5, jan-dec 2008, pag. 243-252.

http://arqarqt.revistas.csic.es/index.php/arqarqt/article/viewFile/98/95.

[65] Rani Hamrouche, Gilles Klysz, Jean-Paul Balayssac, Jamal Rhazi \& Gérard Ballivy (2012) Numerical Simulations and Laboratory Tests to Explore the Potential of 
Ground-Penetrating Radar (GPR) in Detecting Unfilled Joints in Brick Masonry Structures, International Journal of Architectural Heritage, 6:6, 648-664. https://dx.doi.org/10.1080/15583058.2011.597484.

[66] Tzanis, A. (2016). MATGPR R 3.5 Manual and technical reference. http://users.uoa.gr/ atzanis/matgpr/.

[67] USB Digital Endoscope User Guide. http://www.camera2000.com/download/SEL2533X-manual.pdf.

[68] Ježová, Mertens, \& Lambot. (2016). Ground-penetrating radar for observing tree trunks and other cylindrical objects. Construction and Building Materials, 123, 214225. https://doi.org/10.1016/j.conbuildmat.2016.07.005.

[69] Stockwell, R.G., Manshinha, L. and Lowe, R.P., 1996. Localization of the complex spectrum: The S-transform. IEEE Trans. Signal Proces., 44, 998-1001. https://pdfs.semanticscholar.org/2b02/b060dfc573d0d122d43ac5e1cf936614df8c.pdf.

[70] Irving, J.D. and Knight, R.J., 2003. Removal of wavelet dispersion from groundpenetrating radar data. Geophysics, 68 (3), 960-

970.https://pangea.stanford.edu/research/enviro/papers/Irving $\% 20$ and $\% 20$ Knight $\% 20(2$ 003).pdf.

[71] Colomer, J.P. (1967). Crónica de Ripoll. La cripta del monasterio Revista de Girona, 41, 71-73.

https://www.raco.cat/index.php/RevistaGirona/article/view/80750/105195. 